\title{
A Mutant Rat with Congenital Skeletal Abnormalities and Polycystic Kidneys
}

\author{
Kyoko OH.NO and Kyoji KONDO \\ Laboratory of Experimental Animals, Yagi Memorial Park, \\ Mitake, Kanigun, Gifu 505-01, Japan
}

(Received 6 December 1988/Accepted 13 January 1989)

\begin{abstract}
The newly found mutant rat was characterized by small body size, shortened broad skull, slightly shortened limbs and flattened thorax due to shortened ribs and lordosis of thoracic vertebrae. Another distinctive feature of this mutant was polycystic kidneys. The reproductive ability was poor and it died at $6 \sim 11$ months of age. These constitutional skeletal abnormalities and polycystic kidneys were found to be inherited by an autosomal recessive gene, to which the gene symbol, chi, was proposed.
\end{abstract}

In the breeding process of new inbred strains from random bred rats called $\mathrm{Crj}$ : Wistar, one male and two female rats with short faces were found. Namely, the distance between both eyes was wider than those of normal rat and the face was somewhat shortened. These features resembled the characteristics of the Chin dog, a Japanese breed of pet dog, hence the character was named as chin. Chin rats had not only facial abnormalities but also constitutional skeletal abnormalities. Moreover, they showed polyuric symptoms and anatomical observation revealed enlarged and polycystic kidneys.

As for similar mutations in rats, Nash et al. [5] have reported an autosomal dominant mutation affecting the facial structure, and Solomon [7] has found inherited renal cysts. Both the abnormal facial structure and cystic kidneys were observed in all chin rats. The present report is concerned with anatomical observation and genetic analysis on the new character.

\section{Materials and Methods}

Our original colony was derived from 4 males and 4 females of $\mathrm{Crj}$ : Wistar (Charles River Japan, Inc.), and sib-matings were started in 1985. Chin rats were found in the $F_{2}$ generation, and chin rats and their normal littermates from a stock sib-mated for 2 to 8 generations were used in this study. The normal $\mathrm{BN} / \mathrm{fMai}$ strain, used for mating experiments, was introduced from the Institute of Laboratory Animals, Kyoto University in 1984 and maintained in our laboratory by sib-mating.

All the rats used in the present study were maintained in conventional rooms at $18 \sim$ $28^{\circ} \mathrm{C}$ and $12 \mathrm{~L} 12 \mathrm{D}$ of controlled light. One male and one female were housed in a polycarbonate cage with wood shavings. Usually a corrugated paper box containing some chopped pieces of hay was used as breeding nest. Commercial diet (CE-2 ; CLEA Japan, Inc.) and tap water were provided ad libitum.

The body weight and organ weights of chin rats and their normal littermates were measured at $1,2,3,4,5$ and 6 months of age. Skeletal observation was performed by the usual alizarin staining method. Measurements for skull and limbs were carried out with specimens taken at 5 months of age; they were boiled, picked clean, dried and measured with a slilding caliper. Histological study of kidneys was carried out at 2 and 6 months of age. The serial sections were cut at $10 \mu$ and stained with hematoxylin and eosin.

\section{Results}

Characteristics of chin rats 
External observation : The adult chin rats could be distinguished from their normal littermates by the small body size, abdominal distention, shortened facial structure, broad distance between eyes, and the shortened hind legs and feet. The difference was not conspicuous till 5 weeks of age but became clearer with aging. After this age, the growth of chin rats was slightly retarded and they never attained normal weight through their lives. After 4 months of age, they got rough hair and showed polyuria that amounted to $2 \sim 3$ times of the normal littermates. All chin rats died between 6 and 11 months of age (fig. 1).

Skeletal abnormalities: Table 1 shows the comparison of the external and skeletal measurements between chin rats and their

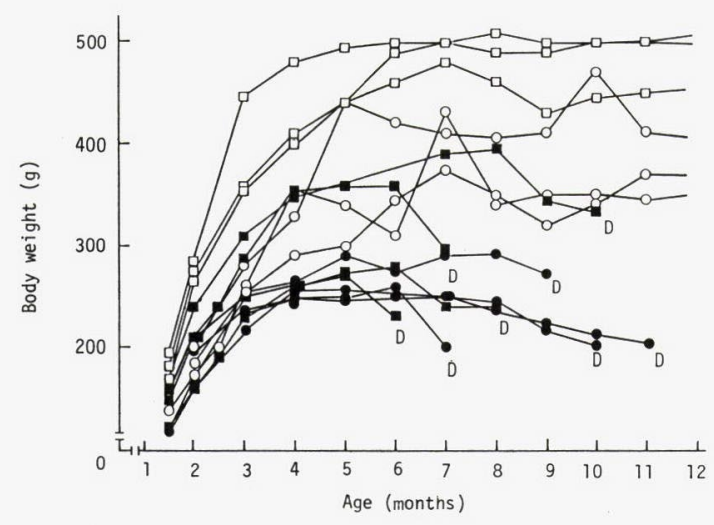

Fig. 1. Growth and life span of chin rats and their normal littermates : chin male : chin female $\square$ : normal male $\bigcirc$ : normal female $\mathrm{D}:$ death normal littermates at 5 months of age. Both in males and females, chin rats showed a remarkable shortening of skull length but no reduction in skull width. The length of the nasal and frontal bone was reduced to 86 and $77 \%$ of the normal littermates respectively, but no reduction was observed in their width. The axial lengths such as head-body length andtail length of chin rats were shortened, although the numbers of vertebral bones were equal to the normal, i. e., 7 cervical, 13 thoracic, 6 lumbar, 4 sacral and 28 30 caudal vertebrae. Chin rats had short ribs and marked thoracic lordosis and hence the thorax was flattened dorso-ventrally and reduced in volume (Fig. 2). The junction of osseous and cartilaginous rib had a spatulate appearance. The length of limb bones such as femur, tibia, humerus, radius and ulna was shortened to $82 \sim 94 \%$ as compaired with the normal littermates. Particularly the metatarsal bone showed remarkable shortening of its length, being about $80 \%$ of the normal (Table 1). All of these abnormalities were slightly noticeable at 2 months of age and after that became severe with aging.

Polycystic kidneys : Table 2 shows the organ weights and their relative weights of chin rats and their normal littermates at 5 months of age. The obvious increase in relative weight of chin rats occured mainly in kidneys and spleen. Relative weight of other organs was similar between the chin and normal rats. Figure 3 shows that the relative kidney weight of chin rats increased with age. The difference from the normal littermates was significant at $0.1 \sim 5 \%$ level after 2 months of age. Histological observation of kidneys of chin rats
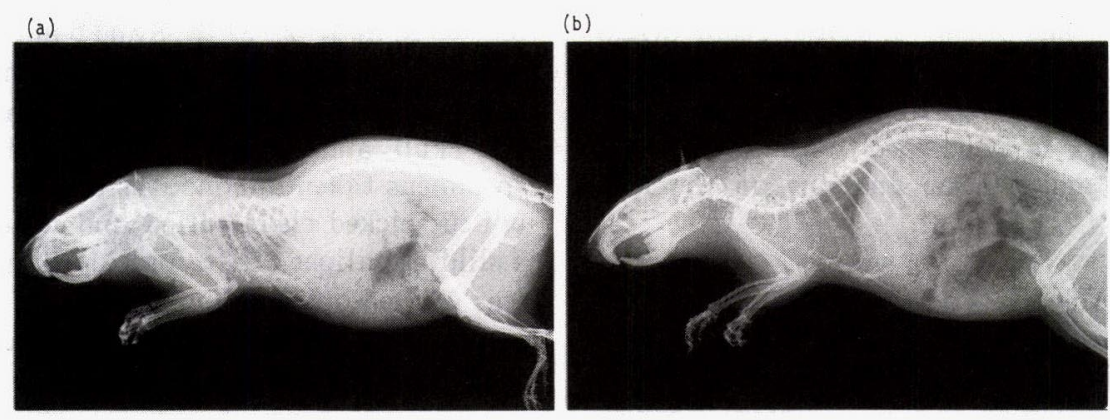

Fig. 2. X-ray photographs of a female chin rat (a) and a normal female littermate (b) at 5 months of age. The thoracic lordosis and the associated reduction in the volume of thoracic cavity is seen in the affected chin female. 
Table 1. Comparison of external and skeletal measurement between chin rats and their normal littermates at 5 months of age

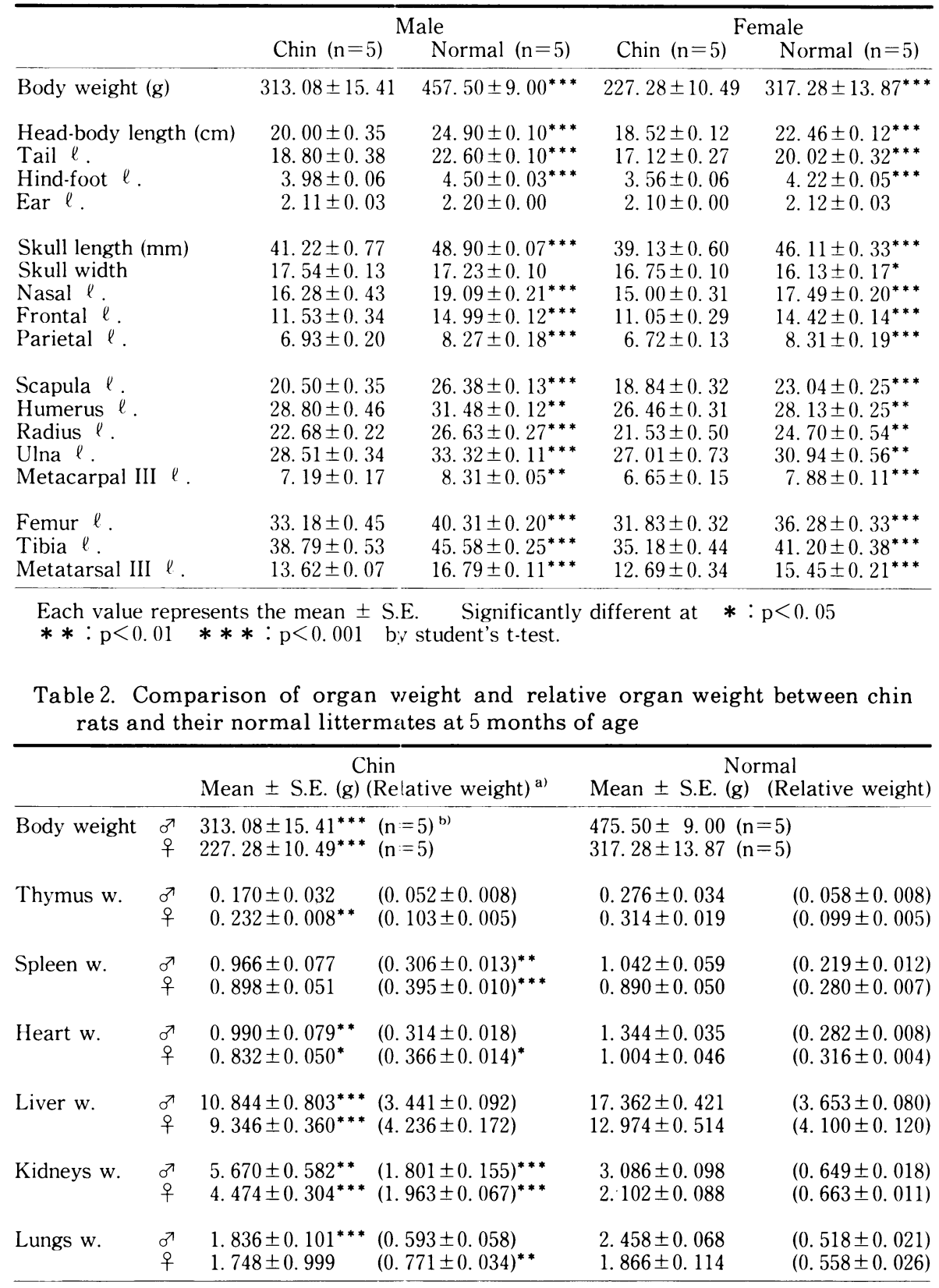

Significantly different at $*: \mathrm{p}<0.05 * *: \mathrm{p}<0.01 \quad * * *: \mathrm{p}<0.001$ by student's t-test (Normal v.s. Chin) a) Mean value $( \pm$ S.E.) of organ weight $/ 100 \mathrm{~g}$ body weight

b) Number of rats examined

showed many small cysts in both cortex and medulla at 2 months of age, and the cysts were increased in both size and number at 6 months of age (Fig. 4). In all chin rats at $7 \sim 11$ months of age, many expanded cysts were observed on the surface of kidneys with the naked eye (Fig. $5)$.

Reproductive ability : Table 3 shows repro- 
ductive data of the chin rat. New borns were never obtained from the matings between chin females and males. In the matings of chin females and normal males, only one female produced a single litter and a few other females

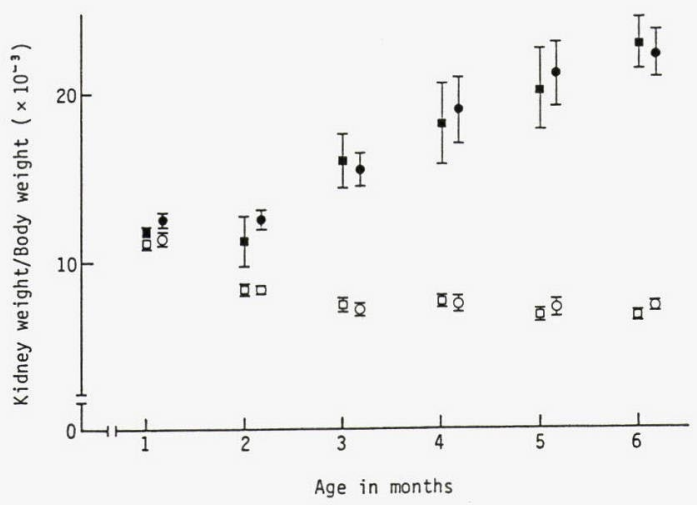

Fig. 3. Comparison of relative kidney weight between chin rats and normal littermates chin male $\square$ : normal male : chin female : normal female 5-8 rats were examined in each group. showed signs of abortion. Some of the chin males before 6 months of age could fertilize normal females, but their litter sizes were smaller than those of normal pairs.

\section{Genetics}

Family history : Table 4 shows the frequency of chin rats among the offspring of normal pairs that produced at least one chin rat. The frequency was $45 / 179(25.1 \%)$ in the males and 55/179 (30.7\%) in the females. The total frequency of the chin rat was $27.9 \%$ (100/358). Table 5 shows the frequency of chin rats among the offspring from the matings of chin

Table 3. Mean litter size in four types of mating pairs in the breeding colony of chin rats

\begin{tabular}{lccc}
\hline $\begin{array}{l}\text { Mating pairs } \\
\text { Female Male }\end{array}$ & $\begin{array}{l}\text { No. of } \\
\text { pairs }\end{array}$ & $\begin{array}{c}\text { No. of } \\
\text { litters }\end{array}$ & $\begin{array}{c}\text { Litter size } \\
(\text { mean } \pm \text { SD) }\end{array}$ \\
\hline Chin $\times$ Chin & 7 & 0 & - \\
Chin $\times$ Normal & 10 & 1 & 4 \\
Normal $\times$ Chin & 16 & 23 & $7.9 \pm 3.0$ \\
Normal $\times$ Normal & 25 & 44 & $10.5 \pm 3.3$
\end{tabular}

(b)

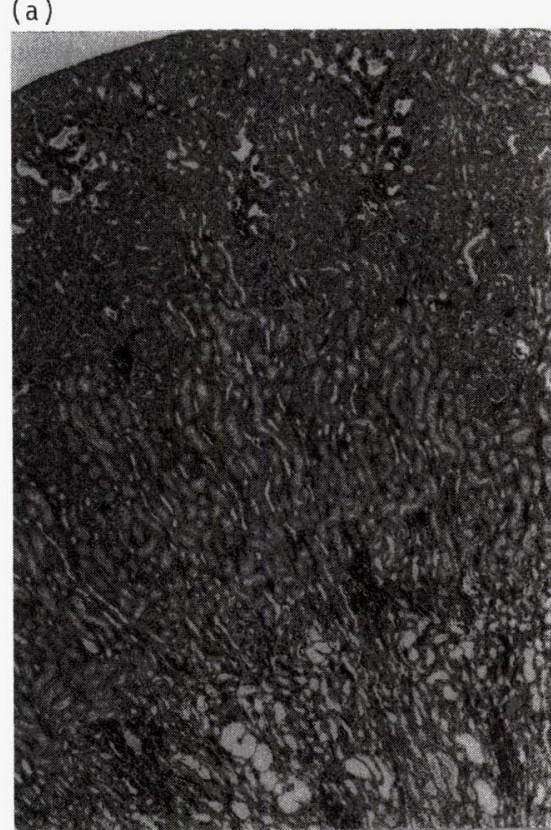

Fig. 4. Microphotographs of kidneys of chin rats. Several small cysts are observed in both cortex and medulla at 2 months of age (a), and size and numbers of cysts increase at 6 months of age (b). 


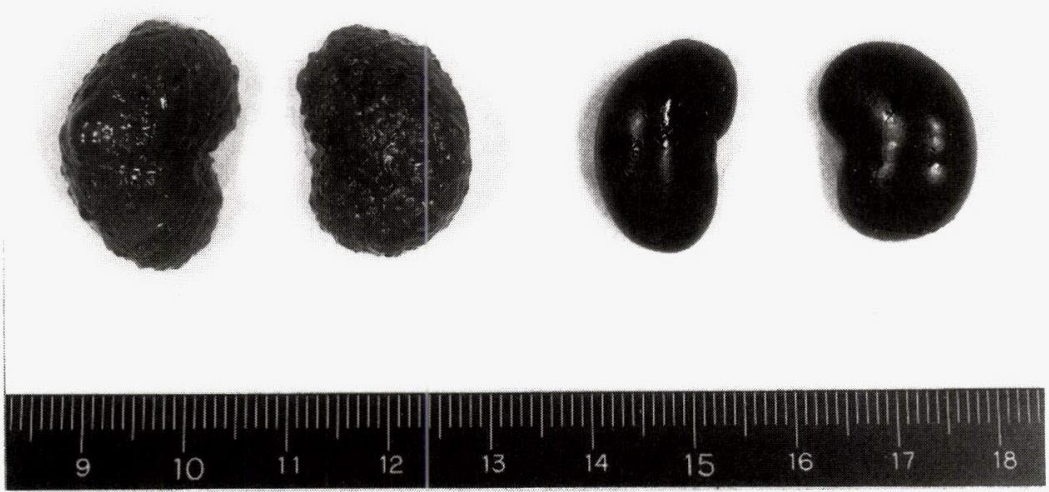

Fig. 5. Kidneys of a chin rat (left) and a normal littermate (right) at 9 months of age. Many visible cysts are present on the kidney surface of the chin rat.

Table 4. Frequency of chin rats in 34 litters produced by phenotypically normal pairs that produced one or more chin offspring

\begin{tabular}{lcccc}
\hline \multirow{2}{*}{ Sex } & \multicolumn{3}{c}{ No. of offspring } & \multicolumn{2}{l}{$\begin{array}{l}\text { Frequency of } \\
\text { chin rats } \\
(\%)\end{array}$} \\
\cline { 2 - 4 } & Normal & Chin & Total & \\
\hline Female & 124 & 55 & 179 & 30.7 \\
Male & 134 & 45 & 179 & 25.1 \\
Total & 258 & 100 & 358 & 27.8 \\
\hline
\end{tabular}

Table 5. Frequency of chin rats in 18 litters produced by the matings of chin males and phenotypically normal females that produced one or more chin offspring

\begin{tabular}{lcccc}
\hline Sex & \multicolumn{3}{c}{ No. of offspring } & \multirow{2}{\text{Frequencyof}}{$\begin{array}{l}\text { chin rats } \\
(\%)\end{array}$} \\
\cline { 2 - 4 } & Normal & Chin & Total & \\
\hline Female & 31 & 39 & 70 & 55.7 \\
Male & 33 & 30 & 63 & 47.6 \\
Total & 64 & 69 & 133 & 51.9 \\
\hline
\end{tabular}

Table 6. Results of mating experiments between chin male and normal $\mathrm{BN}$ rats

\begin{tabular}{|c|c|c|c|c|c|c|c|c|}
\hline \multirow{3}{*}{$\begin{array}{l}\text { Mating pairs } \\
\text { Female Male }\end{array}$} & \multirow{3}{*}{$\begin{array}{l}\text { No. of } \\
\text { pairs }\end{array}$} & & \multicolumn{5}{|c|}{ No. of progeny } & \multirow{3}{*}{$\mathrm{X}^{2}$-test } \\
\hline & & & \multicolumn{2}{|c|}{ Normal } & \multicolumn{2}{|c|}{ Chin } & \multirow[t]{2}{*}{ Total } & \\
\hline & & & Female & Male & Female & Male & & \\
\hline $\mathrm{BN} \times \mathrm{Chin}$ & $2(2)^{\text {a) }}$ & ob. & 5 & 8 & 0 & 0 & 13 & \\
\hline $\mathrm{F}_{1} \times$ Chin & $3(10)$ & $\begin{array}{l}\text { ob. } \\
\text { ex. }\end{array}$ & $\begin{array}{l}27 \\
30.75\end{array}$ & $\begin{array}{l}34 \\
30.75\end{array}$ & $\begin{array}{l}30 \\
30.75\end{array}$ & $\begin{array}{l}32 \\
30.75\end{array}$ & $\begin{array}{l}123 \\
123\end{array}$ & $0.8699^{*}$ \\
\hline $\mathrm{F}_{1} \times \mathrm{F}_{1}$ & $5(33)$ & $\begin{array}{l}\text { ob. } \\
\text { ex. }\end{array}$ & $\begin{array}{l}128 \\
134.6\end{array}$ & $\begin{array}{l}135 \\
134.6\end{array}$ & $\begin{array}{l}50 \\
44.9\end{array}$ & $\begin{array}{l}46 \\
44.9\end{array}$ & $\begin{array}{l}359 \\
359\end{array}$ & $0.9314^{* *}$ \\
\hline
\end{tabular}

$*$ : Expected segregation ratio, $1: 1: 1: 1$ fitting at the level of $0.8<p<0.9$ $* *$ : Expected segregation ratio, $3: 3: 1: 1$ fitting at the level of $0.8<p<0.9$

a) No. of litters 
Table 7. Linkage test between chi and two coat color gene loci, $a$ and $b$, in $\mathrm{F}_{2}$ generation

\begin{tabular}{llcccc}
\hline \multirow{2}{*}{ Locus } & Genotype & \multicolumn{3}{c}{ No. of offspring } & \multirow{2}{*}{$\mathrm{X}^{2}$-test } \\
\cline { 3 - 5 } & & + chi $/-$ & chi $/$ chi & total & \\
\hline a & a $/ \mathrm{a}$ & 52 & 17 & 69 & 0.1993 \\
& $\mathrm{~A} /-$ & 154 & 48 & 202 & $(0.95<\mathrm{p}<0.98)$ \\
& Total & 206 & 65 & 271 & \\
& & & & & \\
b & $\mathrm{b} / \mathrm{b}$ & 54 & 15 & 69 & 0.4366 \\
& $\mathrm{~B} /-$ & 152 & 50 & 202 & $(0.9<\mathrm{p}<0.95)$ \\
& Total & 206 & 65 & 271 & \\
\hline
\end{tabular}

Chin strain: A/A, B/B, c/c, h/h, chi/chi $B N$ strain : a/a, $\mathrm{b} / \mathrm{b}, \mathrm{C} / \mathrm{C}, \mathrm{h}^{\mathrm{i}} / \mathrm{h}^{\mathrm{l}}, \mathrm{C}^{\mathrm{chl} /}+\mathrm{Ch}^{\mathrm{ch}}$

Table 8. Linkage test between chi and two coat color gene loci, $c$ and $b$, in backcross generation

\begin{tabular}{lccccc}
\hline \multirow{2}{*}{ Locus } & Genotype & \multicolumn{3}{c}{ No. of offspring } & \multirow{2}{*}{$\mathrm{X}^{2}$-test } \\
\cline { 3 - 4 } & & $+\mathrm{chi} /-$ & chi/chi & total & \\
\hline $\mathrm{c}$ & $\mathrm{c} / \mathrm{c}$ & 33 & 29 & 62 & 0.6748 \\
& $\mathrm{C} / \mathrm{c}$ & 28 & 33 & 61 & $(0.8<\mathrm{p}<0.9)$ \\
& Total & 61 & 62 & 123 & \\
$\mathrm{~h}$ & $\mathrm{~h} / \mathrm{h}$ & 12 & 15 & 27 & 1.2295 \\
& $\mathrm{~h}$ & 16 & 18 & 34 & $(0.7<\mathrm{p}<0.8)$ \\
& Total & 28 & 33 & 61 & \\
\hline
\end{tabular}

Chin strain: A/A, B/B, c/c, h/h, chi/chi BN strain : a/a, $\mathrm{b} / \mathrm{b}, \mathrm{C} / \mathrm{C}, \mathrm{h}^{\mathrm{i}} / \mathrm{h}^{\mathrm{l}},+\mathrm{chi} /+\mathrm{chi}$

males and normal females that produced at least one chin rat. The frequency was $30 / 63$ $(47.6 \%)$ in the males and $39 / 70(55.7 \%)$ in the females. The average frequency was $51.9 \%$ $(69 / 133)$. These frequencies suggest that the abnormalities are caused by an autosomal recessive gene.

Mating experiment: In order to confirm the single autosomal inheritance of chin character and to get information for its linkage relationship with other genes, mating experiments were perfomed with two chin males and two normal females of BN strain that had never shown any skeletal nor kidney abnormalities. The results are shown in table 6 . Thirteen $\mathrm{F}_{1}$ hybrids (5 males and 8 females) showed agouti coat color with white belly spots and showed no skeletal and kidney abnormalities. Consequently, the coat color genotype of chin rats was inferred to be $A / A, B / B, c / c$ and $h / h$. Next, three $F_{1}$ females were backcrossed to three chin males. The backcross progeny segregated into 61 phenotypically normal and 62 chin rats and sex ratio was normal in both normal andchin rats. The segregation ratio in the $F_{2}$ progeny was 263 normal : 96 chin rats, being in good agreement with the expected ratio of $3: 1$. These results confirmed that the chin character is controlled by an autosomal recessive gene, for which we propose the gene symbol chi. Tables 7 and 8 show the results of linkage tests between chi gene and four coat color genes, $a, b, c$ and $h$. It has been made clear that there are no linkages between chi and these four coat color gene loci.

\section{Discussion}

In rats, there have been no reports on a mutant gene producing both skeletal abnormalities and polycystic kidneys. The pug rat [5]. has a shortened skull which is responsible for an unusual facial structure, inherited by an autosomal dominant gene. Hereditary polycystic kidneys in rats have been reported by Solomon [7]. In this anormaly, the number of visible cysts on the kidney surface increases with age 
after animals are 20 days old. In the chin rat reported here no visible cysts could be found before 6 months of age, but many expanded cysts were observed on the kidney surface at 7 $\sim 11$ months of age with the naked eye. Recently, Suzuki et al. reported a new lethalt mutant rat which shows congenital osteochondrodysplasia with systemic subcutaneous edema (ocd). The ocd/ocd rat dies shortly after birth and shows characteristic external appearances such as shortening of the head, trunk, tail and extremities, systemic subcutaneous edema, protrusion of the tongue and cleft palate[8]. The ocd trait follows a single autosomal recessive inheritance [9]. The chin mutant reported here is inherited by an autosomal recessive gene and also shows shortening of skull and limbs and slight subcutaneous edema possibly resulting from polycystic kidneys. It would be interesting to perform an allelism test on ocd and chi genes, since there are some similarities between the osteochondrodysplasia and chin rat as mentioned above.

In mice, there are a few mutants having shorted long bones and bent thoracic vertebral column due to cartilage anormaly [4] or musculoskeletal abnormalities [3]. Congenital polycystic kidneys in mice have been reported by Russell [6] and others [2, 10]. Dunn [1] reported that the ur/ur mice had urogenital abnormalities associated with other congenital malformations. The majority of them died a day or two after birth, and a few survivors showed hydronephrosis or polycystic kidneys with skeletal abnormalities, which were characterized by a reduction in length particularly in tail and head bones but no decrease in width.

At present, it is not so clear whether the skeletal abnormalities and polycystic kidneys are attributed to the pleiotropism of the chi gene or whether the skeletal abnormalities are secondary malformations caused by functional disorder of polycystic kidneys. The chin rat may become a valuable model for studies of bone metabolism as well as the etiology of polycystic kidney. The details of pathological, physiological and genetical studies are now in progress.

The authors wish to express our thanks Dr. S. Oda, Research Institute of Environmental Medicine, Nagoya University, and Dr. N. Wakasugi, Laboratory of Animal Genetics, Faculty of Agriculture, Nagoya University, for their kind support and valuable advice. We are grateful to Mrs. S. Kato and Mr. Y. Niwa for taking care of the animals. This study was partly supported by Ministry of Education, Science and Culture, Japan (Grant-in-Aid for Scientific Research, No.62109006).

\section{References}

[1] Dunn, L. C. and Gluecksohn-Schoenheimer, S.(1947). A new complex of hereditary abnormalities in the house mouse. J. Exp. Zool, 104, 25-51.

[2] Fox, S. and Eicher, E. M. (1978). New mutants and biochemical variants : juvenile polycystic kidneys (jpk). Mouse News Lett., 58, 47.

[3] Graff, R. J., Simmons, D., Meyer, J., MartinMorgan, D., and Kurtz, M. (1986) . Abnormal bone production associated with mutant mouse genes $p a$ and we. J. Herd., 77, 109-113.

[4] Johnson, D. R. and Wise, J. M. (1971). Cartilage anomaly(can); a new mutant gene in the mouse. $J$. Embryol exp. Morph., 25, 21-31.

[5] Nash, V. G. and Harnden, D. G. (1982). A possible autosomal dominant mutation affecting the facial structure of a strain of hooded lister rats. Rat News Lett., 10, 27-30.

[6] Russell, E. S. and McFarland, E. C. (1977). New mutations : cystic kidneys (ck). Mouse News Lett., 56, 40.

[7] Solomon, S. (1973). Inherited renal cysts in rats. Science, 181, 451-452.

[8] Suzuki, K., Kikukawa, K., and Imamichi, T. (1987). External and skeletal observations on a new lethal mutant of the rat : congenital osteochondrodysplasia with systemic subcutaneous edema. Cong. Anom, 27, 69-84.

[9] Suzuki, K., Kikukawa, K., Hakamata, Y., Kamei, T. and Imamichi, T. (1988). Congenital osteochondrodysplasia with systemic subcutaneous edema (ocd/ ocd) : a new lethal autosomal recessive mutant of the rat. J. Hered. 79, 48-50.

[10] Takahashi, H., Ueyama, Y., Hibino, T., Kuwahara, Y., Suzuki, S., Hioki, K., and Tamaoki, N. (1986) . A new mouse model of genetically transmitted poly. cystic kidney disease. J. Urol, 135, 1280-1283. 


\section{先天性の骨格異常と囊胞腎を呈するラット \\ 大野京子・近藤恭司 \\ 八木記念パーク実験動物研究所}

Crj：Wistar 由来のラットの中に骨格異常と腎奇形 を呈する突然変異個体が発見された。正常個体に比べて 成長が悪く, 短い頭蓋と四肢をもち, 胁骨が短く胸椎が 前彎しているために扁平な胸腔を呈していた。また両側 性の多発性衰胞腎も認められ, 雌雄ともに繁殖能力は低
く，6〜11ヶ月龄で死亡した。家系調査扣よび交配実験 の結果から，これらの異常形質は常染色体上の単一劣性 遺伝子により支配されていることが示された。そこでこ の遺伝子を chi と呼ぶことにした。 